Canadian Studies in Population, Vol. 29(2), 2002, pp. 195-225

\title{
Earning and Caring: Demographic Change and Policy Implications
}

\author{
Roderic Beaujot \\ Department of Sociology \\ University of Western Ontario \\ London, Ontario, Canada
}

\begin{abstract}
Seeking to define families as groups of people who share earning and caring activities, we contrast theoretical orientations that see advantages to a division of labour or complementary roles, in comparison to orientations that see less risk and greater companionship in a collaborative model based on sharing paid and unpaid work, or co-providing and co-parenting. It is important to look both inside and outside of families, or at the changing gendered links between earning and caring, to understand change both in families and in the work world. It is proposed that equal opportunity by gender has advanced further in the public sphere associated with education and work, than in the private family sphere associated with everyday life. Time-use data indicate that, on average, men carry their weight in terms of total productive time (paid plus unpaid work), but that women make much more of the accommodations between family and work. Fertility is likely to be lowest in societies that offer women equal opportunity in the public sphere but where families remain traditional in terms of the division of work. Policies are discussed that would reduce the dependency between spouses, and encourage a greater common ground between men and women in earning and caring.
\end{abstract}

Key Words: Working families, paid and unpaid work, gender, family policy 
Roderic Beaujot

\section{Résumé}

Seeking to define families as groups of people who share earning and caring activities, we contrast theoretical orientations that see advantages to a division of labour or complementary roles, in comparison to orientations that see less risk and greater companionship in a collaborative model based on sharing paid and unpaid work, or co-providing and co-parenting. It is important to look both inside and outside of families, or at the changing gendered links between earning and caring, to understand change both in families and in the work world. It is proposed that equal opportunity by gender has advanced further in the public sphere associated with education and work, than in the private family sphere associated with everyday life. Time-use data indicate that, on average, men carry their weight in terms of total productive time (paid plus unpaid work), but that women make much more of the accommodations between family and work. Fertility is likely to be lowest in societies that offer women equal opportunity in the public sphere but where families remain traditional in terms of the division of work. Policies are discussed that would reduce the dependency between spouses, and encourage a greater common ground between men and women in earning and caring.

Key Words: Working families, paid and unpaid work, gender, family policy

\section{Introduction}

Demographic change is used here in the broad sense of participation in activities across population groups. The activities being considered are earning and caring, or paid and unpaid work, production and reproduction. Taking a family perspective, the paper first considers definitions and theoretical questions, then looks at change in terms of (1) gender and education, (2) gender and work, (3) gender and everyday life. After considering the personal side of sharing in relationships, the paper ends with reflections on implications for fertility and for policy.

\section{Definitions}

Defining families is a minefield. This can be observed by looking at the Cairo conference on Population and Development, and the Beijing International Conference on Women. These conferences might have elaborated some consensus thinking with regard to families, but that proved impossible. At the heart of the problem is not only the diversity of families, but also the conflicting 
orientations at the policy level. On the one hand, there is interest to support or empower families, as a way of supporting individuals and children in particular. But sometimes policy needs to support the removal of individuals from families when these are oppressive or abusive toward their members.

There is much interest in families; people identify with families, and resent the label of non-family household. Even people living alone see themselves as being in a family situation. For instance, a French survey found that for persons who were single at ages $21-44$, at least a quarter were in a serious relationship (Leridon and Villeneuve-Gokalp, 1994: 51). They were not living with someone, but they considered that they were in a relationship.

One solution to the problem of definitions is that adopted in the census monograph by Péron and his co-authors (1999), Canadian families at the approach of the year 2000. This monograph looks mostly at the various family experiences of individuals without implying that those without those experiences are somehow out of the norm.

But we still need to define families in order to locate them in the field. Statistics Canada has evolved definitions that are restrictive, but at least serve the purpose of clear identification. In some regards, there were advantages in the definitions used in some earlier censuses, where a family, or a household, were sometimes simply taken as the people who regularly eat out of the same pot. This provides an interesting definition because it involves preparing meals and eating, important family activities, as are the activities of bringing in the food, which might include the paid work through which food is purchased.

Families are thus usefully defined around earning and caring, or the sharing in earning and caring. In important regards, families are people who mange together the central life-maintaining activities of earning a living and caring for each other. At least families that do not succeed to earn a living and care for each other are under significant stress. Coltrane (1998) even proposes that in order to maintain solid middle class status, people have to "get it together" in both family and work terms.

For most people, there are three key priorities for the core of adult life: living in an enduring relationship, having children, and having meaningful work (Lapierre-Adamcyk, 1990). It is often quite clear that these are priorities for most people, but the difficulty is juggling and accommodating these priorities: relationships, children, and work. Stated differently, the tension between caring and earning provides a useful way to understand a great deal of contemporary family life. My purpose is to look at the distribution of earning and caring activities, the sharing in these activities, and associated implications. 
Roderic Beaujot

\section{Theory}

As in other areas of sociology, it is possible to get some mileage by starting with structural and cultural perspectives. I have always liked Hamilton's (1978) title, The Liberation of Women: A Study of Patriarchy and Capitalism as a means of highlighting these cultural and structural questions. In Le travail au féminin, Kempeneers (1992) considers especially labour force interruptions as a key indicator of the interface or accommodations between production and reproduction. She divides theoretical orientations into three types.

Patriarchy starts with men's authority over women and the consequences for sexual allocation of labour. In the marxist feminist orientation, women have a different relation to production than men, and women's status follows from their greater involvement in domestic work or private production. Feminist marxists do not give causal priority to either men's authority over women (patriarchy) or to women's greater involvement in domestic work (relations of production). This orientation emphasizes the need for paid and unpaid work to be analysed in terms of the dialectic relation between the two systems, that is, between patriarchy and relations of production, or between cultural and structural considerations.

In historical terms, issues of gender and paid and unpaid work are well theorized by Lerner (1986) who proposes that class differences were first experienced through patriarchal relations, which thus preceded other forms of class formation. Gender inequality and its structural manifestation as patriarchy ("paternalistic dominance") can be an exchange of "submission for protection," or "unpaid labour for maintenance." This interpretation sees gender inequality as resulting from accommodations at the family level in terms of the dimensions of earning a living and caring for others - in effect, the division of labour in families. Starting with the "manifestation and institutionalization of male dominance over women and children in the family," there follows an "extension of male dominance over women in the society in general."

The centrality of the division of earning and caring activities can be seen in relation to family models that contrast a Durkheim/Parsons/Becker model based on complementary roles associated with differential responsibility for instrumental and expressive activities, with a companionship or collaborative model. Companionship refers to the relationship being held together through expressive activities. In a collaborative model, men and women both play providing and caring roles. They are collaborating in earning and caring; if there are children it may be seen as co-providing and co-parenting.

Depending on the relative opportunity structure of women and men, this collaborative model provides insurance against the inability or unwillingness of the breadwinner to provide for (especially former) spouse and children. Using terms from Durkheim, the contrast between complementary roles and 
companionship may be seen as the divergence between a family based on organic solidarity (division of labour) and one based on mechanical solidarity (sense of common identity). Goldscheider and Waite (1991) have expressed these ideas about family models in their title New families, No families? Similarly, Conway (1997) speaks of a "joyous funeral" for the patriarchal family based on complementary roles.

As is well recognized, relationships based on companionship are less stable than those based on division of labour. They are also less institutionalized (Harris, 1983). Relationships are not maintained as institutions, but as a "project de couple" (Roussel, 1979), or as a "pure relationship" (Giddens, 1991). Similarly, Burgess et al. (1963) spoke of a movement from institution to companionship, or Farber (1964) from orderly replacement of generations to permanent availability, or Scanzoni and Scanzoni (1976) from instrumental to expressive relationships. Clearly, this comes with a greater flexibility in spousal relationships, seen especially through cohabitation and divorce as forms of entry and exit from relationships.

Rather than these high sounding concepts, we can go back to Adam and Eve. Van Leeuwen (1998) observes that the biblical call was to "be fruitful and multiply" and to "have dominion over the earth." In the usual rendition of this mission statement, it was not for Eve to be fruitful and multiply while Adam was to dominate the earth. The call was given to the couple, to both men and women.

My thesis is that one has to look both inside and outside of families, or at the changing gendered links between earning and caring, to understand change both in families and in the work world. In the sections that follow, I will use categories proposed by Chesnais (1987) to the effect that moving toward gender equality involves equal opportunity (1) in education, (2) in the labour force and (3) in everyday life.

\section{Gender and Education}

It is not hard to demonstrate that there has been much change in terms of gender and education. In 1960 only a quarter of post-secondary students were women, now $56 \%$ are women. Table 1 shows degrees, diplomas and certificates granted by field of study and sex for the period 1970 to 1995 , separating the undergraduate and graduate levels. In several fields, women have become the majority. At the undergraduate level, there are two areas where that is not the case: in engineering and applied sciences the progress is slow such that only $21 \%$ of degrees were granted to women in 1995 , and in mathematics/physical sciences we might speak of proportions that are stalled at some $30 \%$ women since 1980. 
Table 1

Degrees, Diplomas, and Certificates Granted, by Field of Study and Sex for Canada: 1970-95

\begin{tabular}{|c|c|c|c|c|c|c|}
\hline \multirow{2}{*}{$\begin{array}{c}\text { Field of } \\
\text { Study }\end{array}$} & \multicolumn{3}{|c|}{ Undergraduate } & \multicolumn{3}{|c|}{ Graduate } \\
\hline & Male & Female & $\%$ Female & Male & Female & $\%$ Female \\
\hline \multicolumn{7}{|c|}{ Total University } \\
\hline 1970 & 39,514 & 26,224 & 39.9 & 8,604 & 2,236 & 20.6 \\
\hline 1975 & 49,139 & 39,868 & 44.8 & 10,268 & 3,752 & 26.8 \\
\hline 1980 & 49,076 & 49,572 & 50.3 & 10,144 & 5,647 & 35.8 \\
\hline 1985 & 53,888 & 60,184 & 52.8 & 11,170 & 7,657 & 40.7 \\
\hline 1990 & 56,365 & 74,264 & 56.9 & 11,956 & 10,207 & 46.1 \\
\hline 1995 & 61,936 & 88,876 & 58.9 & 14,086 & 13,176 & 48.3 \\
\hline \multicolumn{7}{|l|}{ Education } \\
\hline 1970 & 6,439 & 7,517 & 53.9 & 1,327 & 527 & 28.4 \\
\hline 1975 & 9,562 & 13,169 & 57.9 & 1,892 & 887 & 31.9 \\
\hline 1980 & 7,011 & 14,714 & 67.7 & 1,804 & 1,581 & 46.7 \\
\hline 1985 & 5,369 & 13,054 & 70.9 & 1,508 & 2,060 & 57.7 \\
\hline 1990 & 6,563 & 15,905 & 70.8 & 1,428 & 2,687 & 65.3 \\
\hline 1995 & 7,988 & 18,000 & 69.3 & 1,412 & 3,243 & 69.7 \\
\hline \multicolumn{7}{|c|}{ Fine/applied arts } \\
\hline 1970 & 413 & 836 & 67.0 & 29 & 49 & 62.8 \\
\hline 1975 & 913 & 1,437 & 61.1 & 74 & 72 & 49.3 \\
\hline 1980 & 1,024 & 1,924 & 65.3 & 103 & 105 & 50.5 \\
\hline 1985 & 1,182 & 2,250 & 65.6 & 139 & 191 & 57.9 \\
\hline 1990 & 1,350 & 2,703 & 66.7 & 168 & 259 & 60.7 \\
\hline 1995 & 1,528 & 3,169 & 67.5 & 212 & 331 & 61.0 \\
\hline \multicolumn{7}{|l|}{ Humanities } \\
\hline 1970 & 5,253 & 4,747 & 47.5 & 654 & 1,883 & 34.7 \\
\hline 1975 & 4,689 & 5,782 & 55.2 & 1,051 & 2,429 & 43.3 \\
\hline 1980 & 4,056 & 6,285 & 60.8 & 1,111 & 2,111 & 52.6 \\
\hline 1985 & 4,553 & 7,583 & 62.5 & 1,310 & 2,357 & 55.6 \\
\hline 1990 & 5,915 & 10,579 & 64.1 & 1,514 & 2,763 & 54.8 \\
\hline 1995 & 6,956 & 12,205 & 63.7 & 1,472 & 1,878 & 56.1 \\
\hline \multicolumn{7}{|c|}{ Agriculture/biological sciences } \\
\hline 1970 & 2,258 & 1,299 & 36.5 & 634 & 118 & 15.7 \\
\hline 1975 & 3,038 & 2,356 & 43.7 & 554 & 175 & 24.0 \\
\hline 1980 & 2,969 & 2,827 & 48.8 & 590 & 270 & 31.4 \\
\hline 1985 & 2,636 & 2,981 & 53.1 & 637 & 340 & 34.8 \\
\hline 1990 & 3,352 & 4,244 & 55.9 & 712 & 529 & 42.6 \\
\hline 1995 & 3,598 & 5,405 & 60.0 & 801 & 697 & 46.5 \\
\hline \multicolumn{7}{|c|}{ Social sciences } \\
\hline 1970 & 10,984 & 3,968 & 26.5 & 2,511 & 628 & 20.0 \\
\hline 1975 & 15,483 & 8,390 & 35.1 & 3,642 & 1,113 & 23.4 \\
\hline 1980 & 17,724 & 13,118 & 42.5 & 4,006 & 1,851 & 31.6 \\
\hline 1985 & 20,705 & 21,066 & 50.4 & 4,321 & 2,634 & 37.9 \\
\hline 1990 & 23,255 & 28,876 & 55.4 & 4,471 & 3,573 & 44.4 \\
\hline 1995 & 24,521 & 34,501 & 58.5 & 5,177 & 4,410 & 46.0 \\
\hline
\end{tabular}


Table 1 (Continued)

Degrees, Diplomas, and Certificates Granted, by Field of Study and Sex for Canada: 1970-95

\begin{tabular}{|c|c|c|c|c|c|c|}
\hline \multirow{2}{*}{$\begin{array}{c}\text { Field of } \\
\text { Study }\end{array}$} & \multicolumn{3}{|c|}{ Undergraduate } & \multicolumn{3}{|c|}{ Graduate } \\
\hline & Male & Female & $\%$ Female & Male & Female & $\%$ Female \\
\hline \multicolumn{7}{|c|}{ Engineering/applied sciences } \\
\hline 1970 & 4,214 & 66 & 1.5 & 1,198 & 19 & 1.6 \\
\hline 1975 & 5,138 & 137 & 2.6 & 1,158 & 47 & 3.9 \\
\hline 1980 & 7,348 & 609 & 7.7 & 1,231 & 85 & 6.5 \\
\hline 1985 & 8,297 & 1,056 & 11.3 & 1,766 & 188 & 9.6 \\
\hline 1990 & 7,190 & 1,110 & 13.4 & 1,753 & 252 & 12.6 \\
\hline 1995 & 7,839 & 2,060 & 20.8 & 2,445 & 517 & 17.5 \\
\hline \multicolumn{7}{|c|}{ Health Professionals } \\
\hline 1970 & 1,780 & 2,888 & 61.9 & 424 & 155 & 26.8 \\
\hline 1975 & 2,455 & 3,461 & 58.5 & 434 & 258 & 37.3 \\
\hline 1980 & 2,485 & 4,515 & 64.5 & 423 & 461 & 52.1 \\
\hline 1985 & 2,376 & 5,683 & 70.5 & 589 & 623 & 51.4 \\
\hline 1990 & 2,504 & 6,530 & 72.3 & 710 & 964 & 57.6 \\
\hline 1995 & 2,574 & 7,550 & 74.5 & 887 & 1,462 & 62.2 \\
\hline \multicolumn{7}{|c|}{ Mathematics/physical sciences } \\
\hline 1970 & 3,047 & 643 & 17.4 & 1,245 & 83 & 6.3 \\
\hline 1975 & 3,237 & 897 & 21.7 & 1,098 & 137 & 11.1 \\
\hline 1980 & 3,231 & 1,297 & 28.6 & 959 & 165 & 14.7 \\
\hline 1985 & 5,818 & 2,464 & 29.8 & 1,142 & 300 & 20.8 \\
\hline 1990 & 4,930 & 2,057 & 29.4 & 1424 & 387 & 21.4 \\
\hline 1995 & 5,386 & 2,436 & 31.1 & 1,555 & 502 & 24.4 \\
\hline \multicolumn{7}{|c|}{ Community College and Diplomas } \\
\hline $1970-71$ & 5,929 & 6,873 & 53.7 & & & \\
\hline $1974-75$ & 12,100 & 13,100 & 52.0 & & & \\
\hline $1979-80$ & 19,903 & 27,684 & 58.2 & & & \\
\hline $1984-85$ & 26,303 & 32,345 & 55.2 & & & \\
\hline $1989-90$ & 23,416 & 33,858 & 59.1 & & & \\
\hline 1994-95 & 30,288 & 42,260 & 58.3 & & & \\
\hline
\end{tabular}

Notes: Total includes "unclassified" classification. Undergraduate degrees by discipline are based on University data for bachelor and first professional degrees, as well as undergraduate diplomas and certificates. Graduate data by discipline are based on masters, earned doctorates, and graduate diplomas and certificates. 
Without considering all the reasons for this change or lack of change, part of the explanation may relate to the extent to which various professions have become family friendly. When there are few women in a field, as in engineering or physical sciences, there may be less pressure to adopt family friendly provisions. Thus a circularity may exist wherein certain professions are slow at adopting family friendly orientations because the workers are mostly men, which in turn discourages women from entering the field. In other fields like education or health, where women have become the majority, the workers may have sought benefits that made more accommodations between family and work (Ranson, 1998).

\section{Gender and Work}

We pay much attention to unemployment as a proportion of the labour force, and it has been observed that levels of unemployment have gone up decade by decade, though the averages for the periods 1981-91 and 1991-2001 are very similar at some 9.7 percent unemployed (Beaujot, 2000: 136). We should also consider the employment/population ratio, that is the employed as a percent of the population aged 15 and over. This figure went up from 50 per 100 in 1961 to around 60 per 100 in the period 1981-2001. In spite of an aging population, the employment/population ratio is high by historical standards, due especially to the greater involvement of women.

It could be argued that this greater supply of workers relative to the population, including various kinds of workers with family responsibilities, has been one of the factors bringing change in the nature of work, including what has been called non-standard work (part-time, temporary, multiple jobs, own-account selfemployment, etc). In some regards there is less security at work, but there is also more variety in the types of work, and a higher proportion of workers relative to the population. Presser (1998) proposes that this greater supply of workers of various types is one of the factors underlying a 24 hour economy, which permits a certain accommodation between family and work through part-time work, shifts, and longer hours for retail services. That is, the 24 hour economy, with associated growth of non-standard employment, includes changes at work, in families, and in the relations between family and work.

The labour force participation patterns of women and men have become more similar, but there remain differences in levels and intensity (Beaujot, 2000: 144). A greater proportion of women are working part-time, but part-time work is also increasing for men (Table 2). On average, full-time work is also different for women and men, representing an average week of 44.7 hours for men and 40.0 hours for women in 1996. 


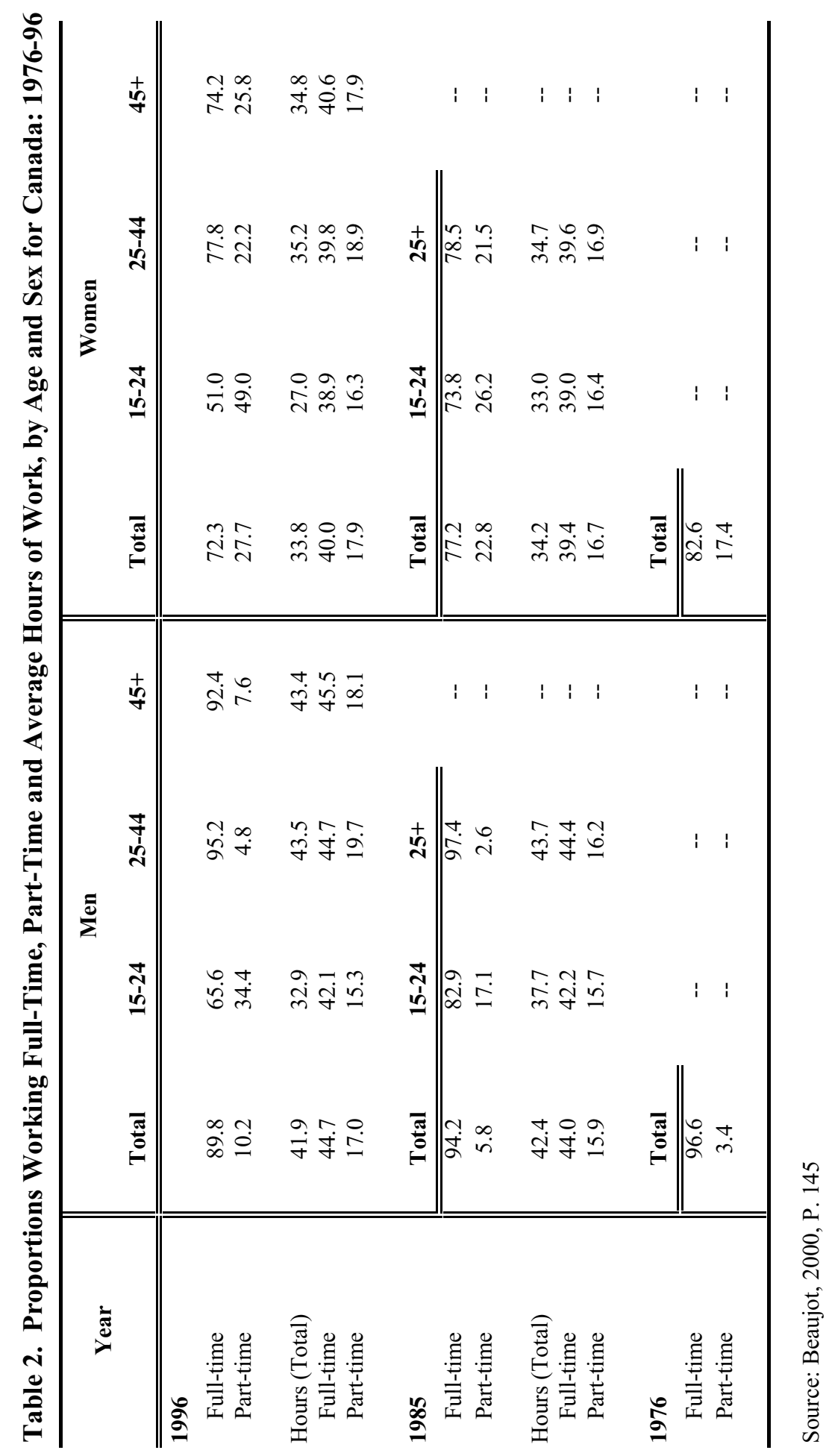


A significant way to look at change for men is to consider the full-time employment/population ratio at ages 25-44. For women, this ratio stayed constant at 52 per 100 between 1986 and 1996 . However, the proportion of men at ages 25-44 working full-time declined from 86 to 75 per 100 (Beaujot, 2000: 144).

Table 3

Managers and Professional s by Sex for Canada: 1976 and 1996

\begin{tabular}{lccc}
\hline \multicolumn{1}{c}{ Category } & Males & Females & Total \\
\hline Managers & & & \\
1976 & 79.8 & 20.2 & 100.0 \\
1996 & 55.0 & 45.0 & 100.0 \\
Professionals & & & \\
1976 & 51.9 & 48.1 & 100.0 \\
1996 & 43.8 & 56.1 & 100.0 \\
Both & & & \\
1976 & 60.5 & 39.5 & 100.0 \\
1996 & 48.5 & 51.5 & 100.0 \\
\hline
\end{tabular}

Source: Beaujot, 2000, p. 147

There is both continuity and change, depending on the indicator. In 1976, women comprised only $40 \%$ of managers and professionals (white collar workers), compared to over half in 1996 (Table 3). On the other hand, while women are $45 \%$ of the labour force, they comprise only $12 \%$ of "power jobs" (corporate officer positions in Canada's 560 largest corporations) and only $3.4 \%$ of "clout positions" (executive vice-presidents and chief executive officers in these largest corporations) (Church, 2000).

Following the categories by Chesnais, equal opportunity by gender for education has basically arrived, and it has also advanced in terms of work, but it is equal opportunity in everyday life that is lagging. 
Earning and Caring: Demographic Change and Policy Implications

\section{Gender and Everyday Life}

In their book entitled Lives of Their Own: The Individualization of Women's Lives, Jones and his co-authors (1990) see a change toward greater alternatives and flexibility in women's lives. Others have questioned whether the growth of part-time work and the double day should be seen as individualization. For instance Duffy and her co-authors (1989) entitle their book, Few Choices: Women, Work and Family. If the choice is to work full-time, that often comes with time stress, especially when there are young children. The housekeeper alternative presents the disadvantage of isolation and low status, The intermediate alternative of part-time work can lead to a lack of seniority and few work benefits.

We have much poorer statistics on everyday life than on education and work, making it difficult to measure change. Nonetheless, change can be implied by comparing two articles in the Canadian Review of Sociology and Anthropology. Based on a 1971 time use study in Vancouver, Meissner et al. (1975) entitled their article "No exit for wives: sexual division of labour and the cumulation of household demands." Figure 1 carries some of the qualitative parts of the study, in terms of men's attitudes. These look rather archaic, as do the attitudes of men in Flin Flon Manitoba in the mid-1970s, captured so well by Luxton's (1980) title, More than a Labour of Love. In contrast Bernier et al. (1996) entitled their Canadian Review of Sociology and Anthropology study "Le travail domestique: tendances à la désexisation et à la complexification," which might be translated as ("domestic work: trends to de-gendering and complexity." Based on data from Sudbury in 1993-94, their analysis of domestic work by age, education, occupation and the relative income of spouses, suggests to these authors that women's paid work was a "trump card" against their exploitation through domestic work. Looking toward the future, Bernier and her co-authors propose that greater labour force participation, along with fewer children, should further reduce the gender differences in housework. The contrast is highest in the qualitative parts of the studies from Vancouver in 1971 and Sudbury in 1993-94. While the Meissner study concludes that there is "no exit for wives," Bernier et al. note a reduction of the inequality in the sharing of domestic work across various types of couples. Based on their data from Hamilton in 1984, Livingstone and Asner (1996) find that the gender differences in domestic work are lowest in professional dual-earner couples who are intermediate in the class structure.

The General Social Surveys on time-use (1986, 1992 and 1998) provide the most consistent data at the national level. It is useful to divide the total 24-hour day for each respondent into four categories. Time use in paid work here includes driving to and from work, and it also includes time spent in education. Unpaid work is all other work, including housework, child care and even volunteer work, performed as a main activity at given times of the day. These two together can be called total productive time. In contrast, the other two 
Roderic Beaujot

categories are down time: personal care including sleeping and caring for oneself, along with leisure and free time which includes active and passive forms of leisure.

\section{Figure 1}

Views of Vancouver men on wives as co-providers, 1971

Ten of the couples in the Meissner et al. (1975) study were interviewed to explore in more depth their feelings and conceptions of the division of paid and domestic work. The selected quotes from five men given below represent the full range of class differences:

A forklift driver in his mid-fifties, whose wife works two days a week as a switchboard operator (three children, aged 13 to 22), had this to say on the conditions of sharing housework: "If a woman has to work, then the husband and wife should share the housework, but if it isn't necessary for her to work then she should consider looking after the house first. It isn't necessary for her to work in the first place. She's doing this for herself and to satisfy herself, where the man has to work to keep the house going."

A skilled repairman in his early forties whose wife had been upgrading her education and is contemplating further training, on the question of his wife taking a job (four children, aged 5 to 16): "I'd want her home when the kids come home from school or at least when I get home from work. I'm sure as hell not cooking my own supper, I didn't get married for that."

A policeman in his early forties whose wife works a few hours a week as a salesperson in a store (two children, aged 9 and 13), on his wife's income: "It doesn't mean anything because it's so little. I told her to put it away into a little account, do whatever you want with it." On reacting to two weeks recently when his wife's job was full time: "To stand back and say there's no way she's going to work steady if this is what it's going to do. It wasn't the money, it was just getting a break from housework to cut the boredom down a little bit and having fun at it and no stress or strain or nothing. Once a job starts to develop the stresses and strains it's not worth it any more. You've lost yours sense of direction."

A manager in his mid-thirties whose wife is a full-time housewife (three children, aged 7 to 14), on the hypothetical question of his wife taking a job: "I wouldn't stand in her way, if that's what she wanted to do, but fortunately for me she doesn't want to do that. My wife's first priority should be the family and the home as long as I am able to provide for the family." 
A lawyer in his late forties whose wife has just quit a part-time professional job because the double burden was too much (three children, aged 15 to 19), about the sharing of housework: "If the guy comes home completely beat because he's got a job of much more pressure and his wife has a job because she's bored with the housework, this gives her a lift and she's more up to doing the housework."

(Source: Meissner, et al., 1975, pp. 438-439)

The results are derived from time-use diaries where respondents are asked to indicate their activity over a specific 24-hour day. Measured here is only the main activity for given times of the day. That is, double tasking is not measured, nor the intensity of the activity, nor the extent to which the respondent takes responsibility for a given task. Nonetheless, time provides a common metric, especially for measuring both paid and unpaid work. There are also advantages to recording the specific activities performed over the day, rather than having respondents estimate the time spent on given activities, or their share of the responsibility for given tasks. Since there is considerable variation from day to day for specific respondents, averages for categories of the population can be more useful than multivariate analyses based on individual responses.

All three surveys show an important result: for the total population aged 15 and over, the average productive time of men and women is very similar. In 1998, the average was exactly the same at 7.8 hours per day for women and men (Figure 2). The asymmetry is in terms of the division of this time into the paid and unpaid components. Nonetheless, there has been some convergence (Table 4). As would be expected, women's time in paid work as a percent of men's time in paid work has increased from $60 \%$ in 1986 , to $65 \%$ in 1992 , and $68 \%$ in 1998. Conversely, men's time in unpaid work as a percent of women's time in unpaid work has also changed from $46 \%$ in 1986 , to $58 \%$ in 1992 , and $61 \%$ in 1998. In 1986 we could say that men did a third and women two-thirds of unpaid work, or women did twice as much as men. This generalization is no longer true, with men doing $61 \%$ as much unpaid work as women

Marital status and the presence of children influence the total time in productive activities and the distribution into paid and unpaid components (Table 5). At ages $25-44$ in 1998 , the greatest gender symmetry can be observed for those who are unmarried (neither married nor cohabiting) with no children. In this category, there is less than an hour of difference by sex in the average hours per day in each of paid and unpaid work. Compared to the category of unmarried without children, married without children increases the total productive time for both men and women, but women's time in paid work declines slightly while that of men increases. Both men and women show an increase in unpaid work, but this applies especially to women who see a change from an average of 2.6 
Figure 2

Relative Share of Time in Productive Activities,

Woman and Men Aged 15 and Over for Canada: 1998

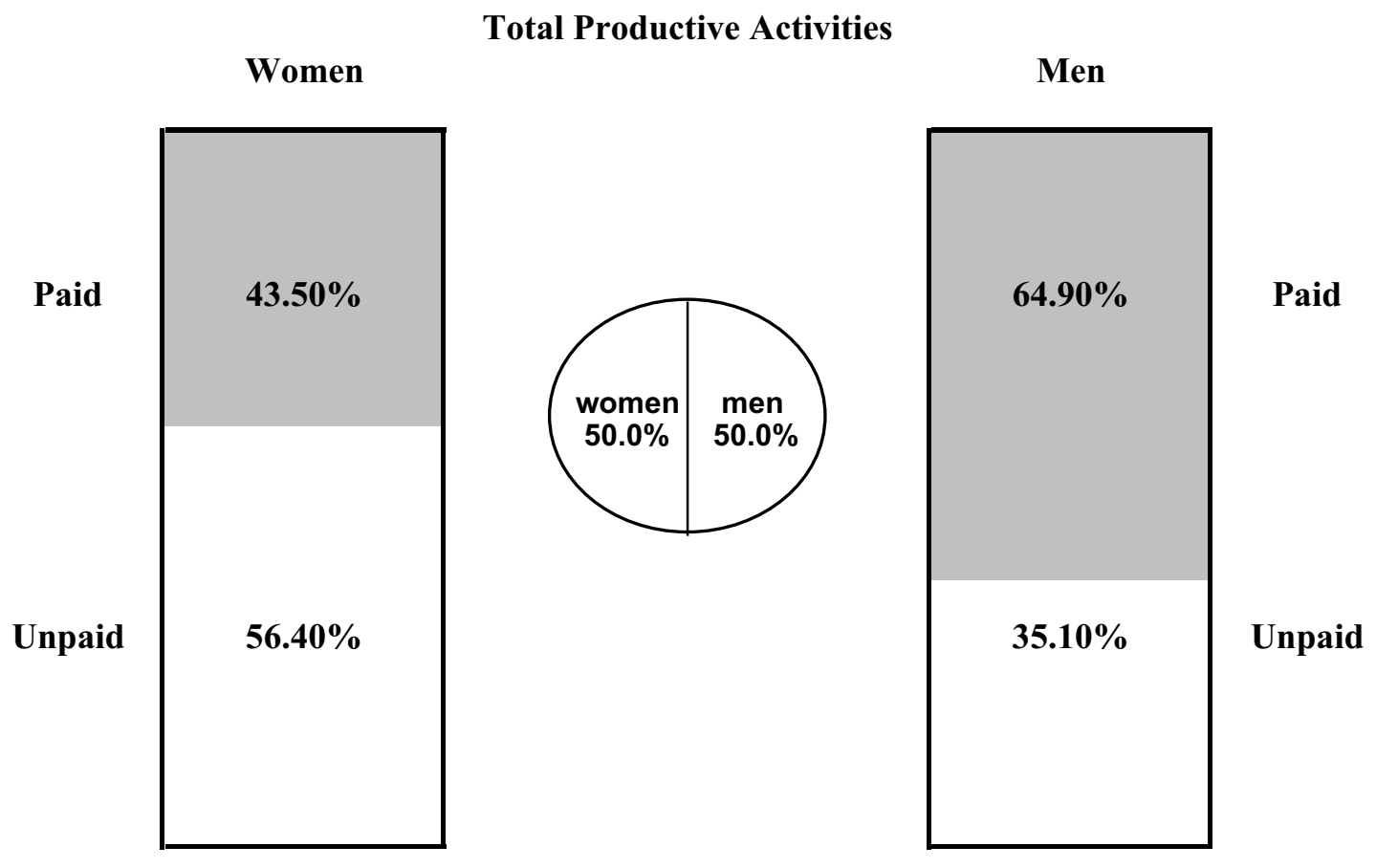

Note: Based on averages per capita.

Source: See Table 4. 
hours of unpaid work when they were unmarried to 3.5 when they are married or cohabiting. Children further increase the total productive time for both sexes, but this increase is all in the unpaid work category, and especially for women. Children reduce the time spent in paid work, slightly for men and considerably for women. Compared to being unmarried without children, being unmarried with children reduces the time in paid work and increases the time in unpaid work. Once again, there are larger differences for women. It is noteworthy that, except for lone parents, the average time in productive activity is very similar between men and women within these categories of marital and parental status for the population aged 25-44. Nonetheless, both marriage and children, but especially children, bring change in the direction of greater complementary or specialization. It can also be seen that women make greater adjustments for changing family situations. As Kempeneers (1992) had observed through looking at work interruptions, women carry more of the responsibility for the necessary accommodations between production and reproduction. As family needs change over the life course, the corresponding adjustments are made more by women than by men.

Table 4

Time Use of Total Population by Sex for Canada: 1986, 1992 and 1998

\begin{tabular}{|c|c|c|c|c|c|c|}
\hline \multirow{3}{*}{ Type of Activity } & \multicolumn{6}{|c|}{ Average hours per day in population aged $15+$} \\
\hline & \multicolumn{2}{|c|}{1986} & \multicolumn{2}{|c|}{1992} & \multicolumn{2}{|c|}{1998} \\
\hline & $\mathrm{m}$ & $\mathrm{f}$ & $\mathrm{m}$ & $\mathrm{f}$ & $\mathrm{m}$ & $\mathrm{f}$ \\
\hline total productive activity & 7.5 & 7.4 & 7.7 & 7.8 & 7.8 & 7.8 \\
\hline Paid work and education & 5.6 & 3.3 & 5.1 & 3.3 & 5.0 & 3.4 \\
\hline unpaid work & 1.9 & 4.1 & 2.6 & 4.5 & 2.7 & 4.4 \\
\hline personal care & 10.8 & 11.2 & 10.3 & 10.8 & 10.2 & 10.6 \\
\hline leisure/free time & 5.7 & 5.3 & 6.0 & 5.5 & 6.0 & 5.6 \\
\hline total & 24.0 & 24.0 & 24.0 & 24.0 & 24.0 & 24.0 \\
\hline
\end{tabular}

Sources: Beaujot, 2000, p. 207; Statistics Canada, 1999, Cat. 12F0080XIE, p. 5; General Social Survey, 1986, 1992 and 1998.

Besides differentiation by marital and parental status, it is useful to differentiate by the employment status at the household level. In the Statistics Canada report on the 1992 survey, Frederick (1995: 27-28) observes that at ages 25-44 the wife's labour force status did not greatly change the unpaid work hours of husbands. In this age group, a husband with a spouse who is not employed 


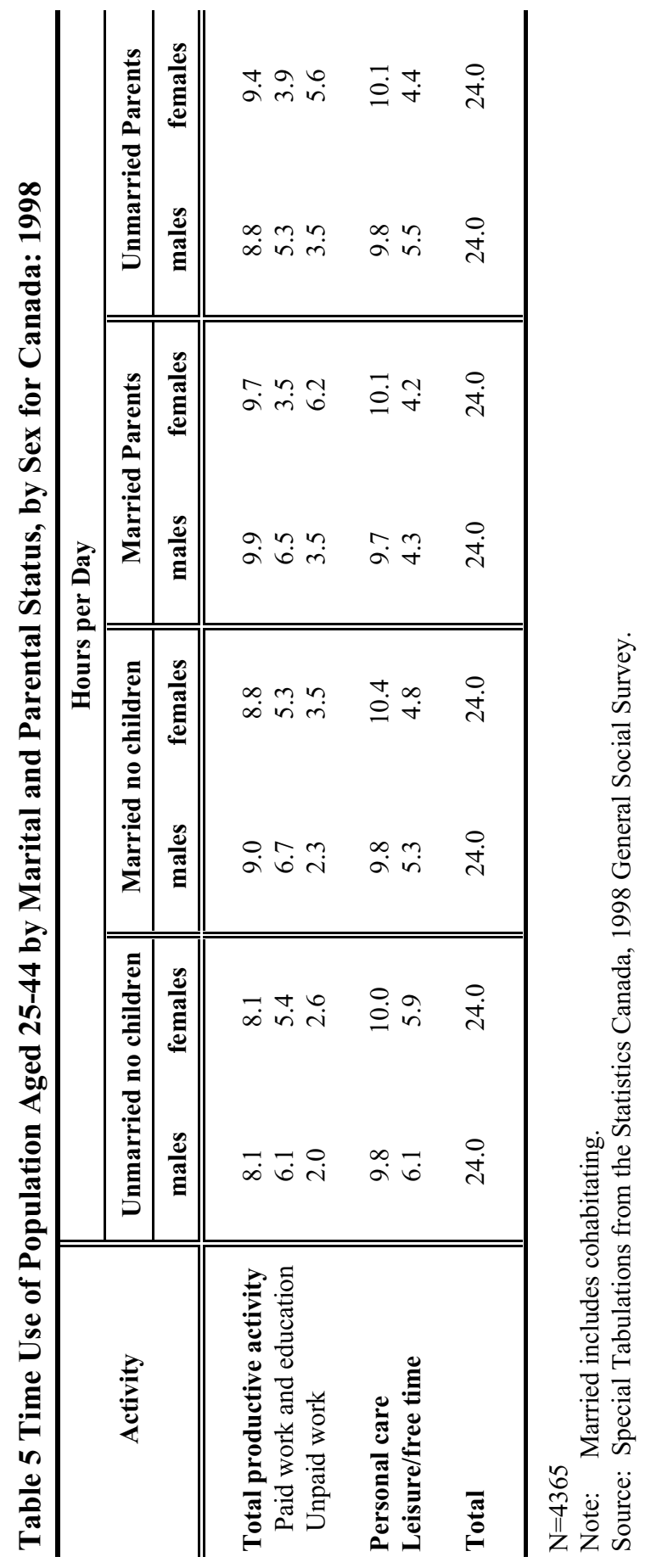


spends more hours (3.1) in unpaid work than a husband whose spouse is employed part-time (2.8 hours) or full-time ( 2.8 hours). Frederick continues, "Contrary to strong anecdotal evidence, the difference in the amount of unpaid work done by dual-earner husbands is not significantly different from other husbands." However, there is need to control for the presence of children. The observation that men whose spouses are not employed are doing the most unpaid work appears surprising until one realizes that these are the households with more children and consequently with more unpaid work.

Table 6 presents results by family type, employment status and presence of children. Once again, the most gender symmetry is for those who are not living in husband-wife families and who have no children. For persons in husbandwife families, the total productive time is highest for both men and women when both are employed full-time. Silver (2000: 27) has further be observed that when both are working full-time, they both spend more time with younger than older children, and the difference between these fathers and mothers in time with children converges over children's ages $0-4$ to $13-14$. When two are employed but not both full-time, both men and women do less paid work and more unpaid work (Table 6). Across parental status, there is considerable variation in unpaid work, and it is systematically in the direction of more unpaid work with children, especially if there are children under 5 years of age, for both men and women. In husband-wife families, men's unpaid work as a proportion of women's is highest when both are working full-time. Nonetheless, these men do only $68 \%$ of the amount of unpaid work of their partners. At the same time, these women working full-time do $82 \%$ of the amount of paid work of their partners. It is noteworthy that for this entire population aged 30-54 in 1998, the average daily hours of productive time is very similar at 9.23 hours for men and 9.26 for women. While these are averages and the differences are sometimes small, in six of the nine specific comparisons for husband-wife families by employment and parental status, the total productive time of men is higher than that of women. Nonetheless, there is more variability in women's time, across the categories of marital, parental and employment status.

Given one respondent per household, the detailed time-use data do not permit comparisons within the household. However, at the end of the survey, respondents were asked to estimate the total time spent in each of four activities for both themselves and their spouse or partner: paid work, housework, maintenance and child care. While there is a high non-response rate in the estimates for the spouse, these estimates allow comparisons in terms of doing more or less of each of paid and unpaid work compared to the spouse. Using within four hours per week as representing about the same number of hours, nine outcomes are possible (Table 7). The basic idea is that compared to the spouse, the respondent could be doing more, about the same, or less of each of paid and unpaid work. It is of interest that there are people in each of the nine cells of the table. 
Table 6

Time Use in Paid and Unpaid Work by Sex, Family Status, Employment Status and Presence of Children, Persons Aged 30 - 54 for Canada: 1998

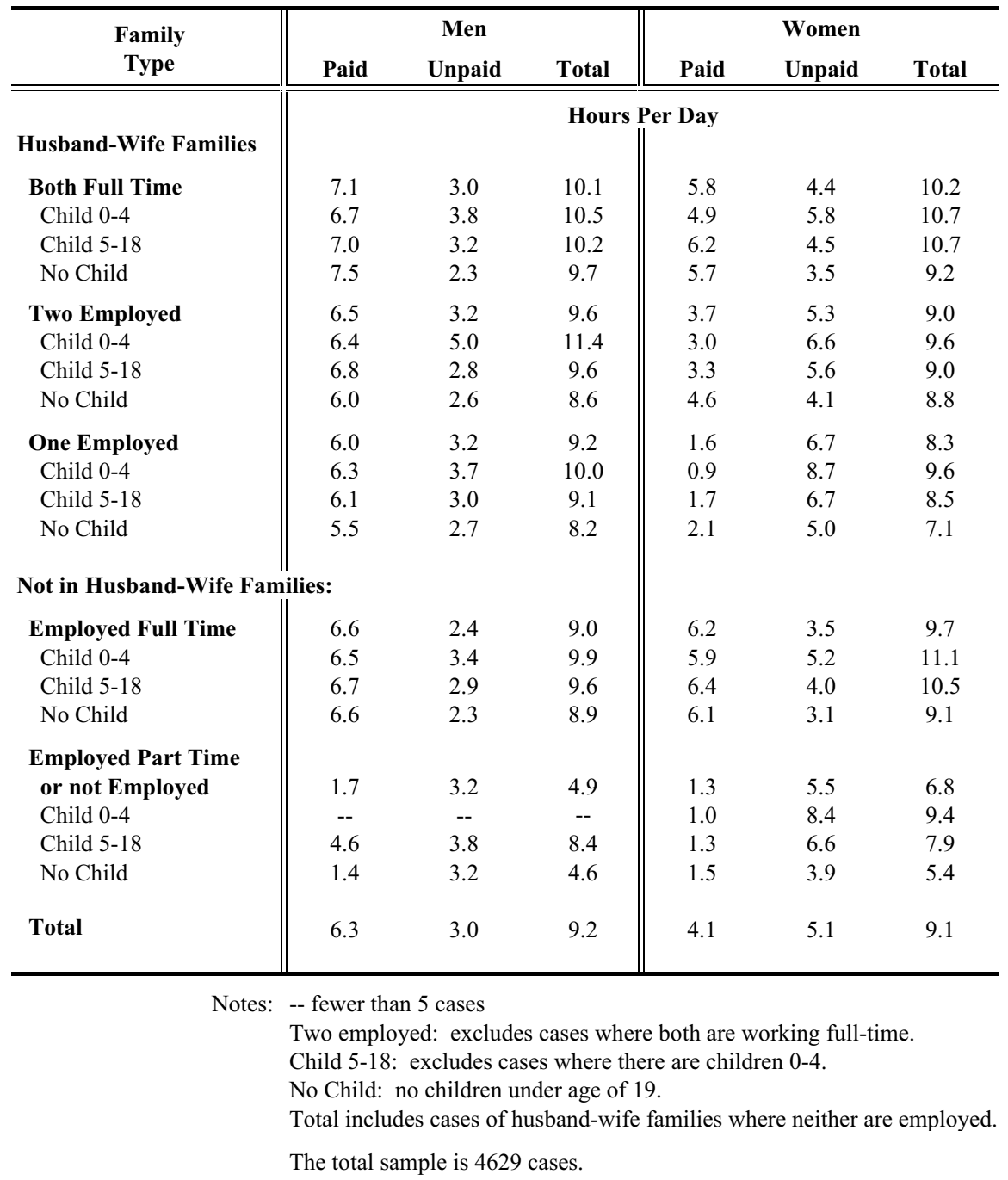

Source: Special tabulations from the Statistics Canada, 1998 General Social Survey. 
Table 7

Predominance of Models of Husband-Wife Families in terms of Relative Participation in Paid and Unpaid Work Respondents Aged 30-54 by Sex for Canada: 1998

\section{Compared to Husband, Wife Does}

\section{More Paid Same Paid Less Paid}

\section{Compared to Husband, Wife Does}

\section{More unpaid}

$\begin{array}{llll}\text { Men } & 3.1 & 12.1 & 49.6 \\ \text { Women } & 9.5 & 15.6 & 50.6 \\ \text { Average } & 6.3 & 13.8 & 50.1\end{array}$

\section{Same unpaid}

$\begin{array}{llll}\text { Men } & 2.6 & 7.3 & 9.8 \\ \text { Women } & 4.6 & 3.8 & 5.9 \\ \text { Average } & 3.6 & 5.6 & 7.9\end{array}$

\section{Less unpaid}

$\begin{array}{llll}\text { Men } & 3.6 & 3.9 & 7.9 \\ \text { Women } & 4.9 & 2.8 & 2.4 \\ \text { Average } & 4.3 & 3.4 & 5.2\end{array}$

$\mathrm{N}=3051$ Cases

Source: Special tabulations from the Statistics Canada, 1998 General Social Survey.

The dominant category, amounting to $54 \%$, are those where one spends more time at paid work and the other spends more time at unpaid work. This is the complementary roles model, with $8 \%$ of these having the man doing more unpaid work and the woman doing more paid work. The second largest category is the double burden where typically a given person is doing the same amount of paid work but more unpaid work. This corresponds to $29 \%$ of the sample; in $70 \%$ of the cases it is the woman who has the double burden. The remaining $17 \%$ of the sample can be called a collaborative model or shared roles, including the $6 \%$ who do the same amount of both paid and unpaid work. Further results based on the 1992 data indicate that the equal sharing of unpaid work is more likely to occur if there is less total work done in the household, and if there are fewer children (Beaujot, 2000: 225). 
Comparisons between 1992 and 1998 show only slight change, but it is systematically in the direction of somewhat greater symmetry. The complementary roles have declined from $58 \%$ to $54 \%$ of couples aged $30-54$. The double burden has remained stable but men's representation in the persons carrying the double burden increased from $25 \%$ to $30 \%$. The shared roles increased from $14 \%$ to $17 \%$ of respondents.

If the distribution of unpaid work is taken to represent the extent of equality of opportunity in everyday life, it is clearly the area that remains most traditional. Some have even referred to a "stalled revolution" in terms of movement toward gender equality (Hochschild, 1989). Compared to equal opportunity in education and at work, it is probably in everyday life that there is the most conflict of interest between men and women. Nonetheless, there are indicators of change, and they are in the direction of men carrying a higher proportion of the weight, just as women are carrying more of the responsibility for providing.

There is probably more change in attitudes than in behaviour. For instance in his study of values in twelve countries, Nevitte (1996) found that between 1981 and 1990 the family remained one of the most important priorities in people's lives, but there was more permissiveness and tolerance surrounding family questions. Especially in Canada, he found that both men and women wanted spousal relations and parent-child relations to be more egalitarian. Among the 24 value dimensions considered, Canadians were most egalitarian when it came to spousal relations and shared responsibilities. This comparison of Canadian values also shows that "sharing household chores" was the only value, among nine factors measured, that increased as an attribute considered important for a successful marriage (idem, p. 247).

On the basis of these various considerations, Coltrane (1998: 176) also ends his synthesis with optimistic projections. Given similar levels of education, with more women employed, the need to have two earners to maintain middle-class standing, and with wages and work hours converging, he expects to see significantly more sharing of family work by men. In particular, he expects new ideals of shared spheres to develop, first in child care and grocery shopping, then in cooking and cleaning.

\section{Sharing as Caring about the Relationship}

More research is needed on the personal side of these questions of the sharing of earning and caring. Thompson and Walker (1989: 855) observe that only a minority of women feel that husbands should do more domestic work. Feree (1991) finds it striking how little explicit conflict there is over housework in many families. The 1984 Canadian Fertility Survey found that 78 percent of women thought that household chores should be shared equally, but only 8.2 
percent indicated that they often had a problem with sharing housework, in spite of the fact that some 70 percent did given tasks "always or mostly" themselves (Balakrishnan et al., 1993: 170-173).

Nonetheless, the division of work is a source of conflict in some marriages, especially when employed women work significantly more total hours than their husbands (Gershuny and Robinson, 1988). The perception of fairness is more important to the personal well being of wives than of husbands (Davies and McAlpine, 1998). Employed wives are found to be less satisfied with their marriage if their husbands fail to share in housework (Yogev and Brett, 1985). Well-being is lowest and depression highest among wives whose husbands do little housework (Ross et al., 1983). Among wives employed full-time, those who report an unfair division of household labour are significantly more likely to report having trouble in their marriage (Bumpass, 1991). However, the sharing of family work has also been associated with greater marital strain, possibly because there are more potential areas of disagreement, negotiation and mutual criticism (Thompson and Walker, 1989: 859).

Spain and Bianchi (1996: 171) conclude that "academic researchers are more troubled by the division of household labor than the women they interview, many of whom think their household arrangement is equitable." This may be because cognitive dissonance brings people to reconcile their expectations with reality. Assessment of fairness may also be a function of the comparison to others, or of perceptions of what is appropriate. However, it is probably also a function of exchange and dependency, with the person who is more economically dependent considering it fair to be doing more of the housework. In fact, Lennon and Rosenfield (1994) find that the distribution of tasks is more likely to be seen as fair by women who have few alternatives to marriage and who have less economic resources.

It may be, as Hochschild (1989) has demonstrated, that some couples maintain a myth about these questions so that it does not undermine their marriages. Couples who do not manage some sense of fairness in the basic division of work are probably more likely to separate. One might even suggest that an unwillingness to carry one's fair burden is an indication that one does not really care about the relationship.

There are also difficulties in changing from one pattern of division of work to another. In particular, as often happens, if one person has done more of the unpaid work because they were doing less of the paid work, subsequent changes in the relative time spent in paid work can sometimes mean difficult accommodations in unpaid work. In her return to Flin Flon, Manitoba, Luxton (1990) demonstrates this with the case of the husband who was taught to do laundry by the wife tricking him to undertake one part of the task at a time, until she managed, after much careful induction, to have him do the whole task. 
Roderic Beaujot

A study from the Netherlands finds that couples could re-negotiate these things only if they were not too far apart at the outset. Kluwer et al. $(1996,1997)$ observed three patterns: avoiding the problem, destructive conflict and constructive conflict. Wives with traditional gender role orientations, and those with traditional husbands, were more inclined to avoid conflict, despite their discontent about the division of labour. When there was high discontent, the most common pattern was destructive conflict, largely manifested as the wife making demands and the husband withdrawing. The constructive conflict of mutually integrative interaction was more likely to occur when the couples had lower levels of discontent. It would seem that conflicts over the division of labour are most likely resolved in a positive direction by couples who already have a reasonably equitable division of labour and are able to engage in positive interactions surrounding conflict. The authors conclude that women have a growing sense of entitlement, but clear difficulties exist in putting these goals into practice in relationships that are not based on considerable mutuality.

\section{Fertility}

It is useful to theorize fertility as involving first proximate factors like contraception and unions, then the individual level determinants of the value and cost of children, and the structural level determinants of the interface of production and reproduction (Beaujot, 2000: 243-262).

The inverse relation between fertility and women's labour force participation is often used in discussions of childbearing and its relationship to paid and unpaid work (Figure 3). This interpretation tends to forget that the inverse relation is largely limited to a period between 1960 and 1975. In the 1950s fertility was going up, as was women's education and their labour force participation. In the last 20 years, fertility has been remarkably stable and labour force participation has continued to rise, with a slight decline in the first half of the 1990s.

McDonald (1997) and Chesnais (1996) propose that fertility is particularly low in countries where the public sector has modernized in terms of women's opportunities in education and work, but where families have remained traditional, especially in terms of the division of work. In such circumstances, women have to choose between the public opportunities and the private limitations, and they often choose to forgo childbearing to solve the problem. In many cases, childlessness is the easiest route to equality. In this interpretation, families have to modernize into "new families" if childbearing is to be sustained. It may be that men's willingness to take on part of the burden is preventing Canadian fertility from declining further. 


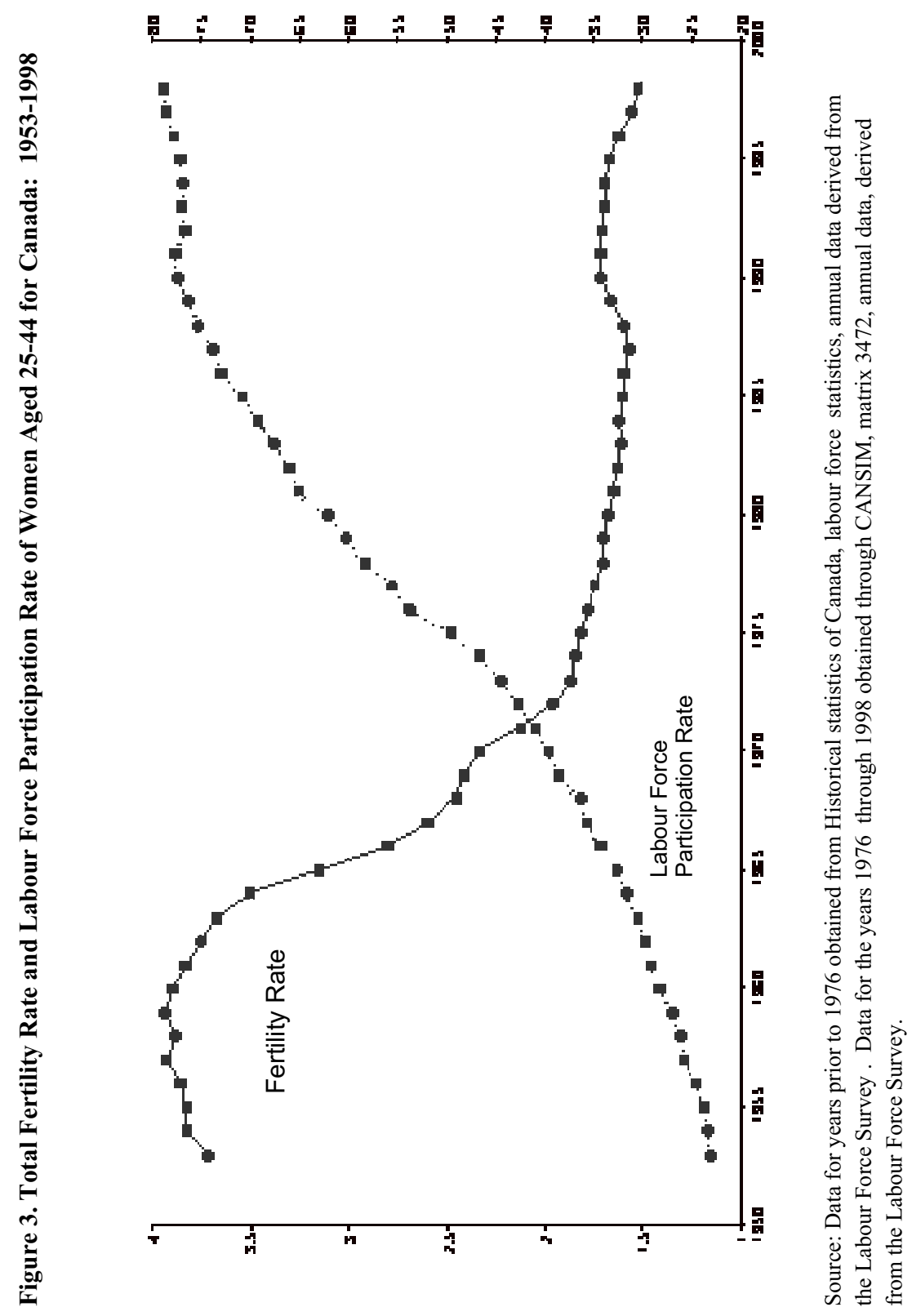


Fertility is also being delayed to later ages. In 1976, births to women at ages 30 or more represented 19.6 percent of births, compared to 43.7 percent in 1996 (Beaujot, 2000: 89). In looking at the various delays experienced by younger generations, Côté and Allahar (1994) are concerned about a Generation on Hold. But these delays also represent an adaptation to a context where the earning potential of both men and women is important. This requires people to invest in themselves longer before they enter the trade-offs associated with investing in the next generation. In addition, women who are not so young are probably better able to negotiate with their partners, and work groups, to share the costs of childbearing.

From the point of view of children, a bifurcation of models has been observed in terms of early and late childbearing. Based on census data, Lochhead (2000) finds that delayed childbearing is more pronounced among women who have university education, and that there are increasing income differentials to the disadvantage of younger first-time mothers, even in two-parent families. Using data from the United States, Martin (2000) finds that delayed childbearers, who tend to have more education, are increasingly likely to raise their children in intact marriages, while early childbearers are more likely to raise children outside of marriage. Canadian data also indicate that women under 30 who are formerly married are much more likely to have children than those who are single, cohabiting or married (Ravanera, 1995: 18). Consequently, Bianchi (2000) speaks of a possible bifurcation of models, with one group taking advantage of parental investment from both mothers and fathers, and the other where fathers are absent and mothers do not have adequate time and resources to invest in children. Children born from mature parents are more likely to have the advantages of a mother with more human capital, along with the presence of a father in a dual-income family, which contrasts with the greater likelihood of lone parenthood for those who parent early.

\section{Policy Implications}

The change that can be observed is toward more equal opportunity in education and at work, but there is inadequate common ground between women and men in family activities, which impedes equal opportunity in everyday life. There is clearly some basis for "new families" including policies like the Ontario Family Law Reform Act which already in 1978 spoke of couples sharing equally in the responsibility for their children.

Policy probably needs to work at three fronts. It is important to seek to achieve more individual self sufficiency. It is also important to have families that look after individuals, and it is important to have a broader social safety net. As in any difficult policy area, there are contradictions. In particular, the encouragement of families to look after individuals can undermine the selfsufficiency of the person who takes the largest responsibility for this care. 
Another problem is that many policies are based on a family wage model, which promotes dependency of one spouse on the other rather than self-sufficiency (see Figure 4). In particular, it would seem that a policy model that wanted to increase the common ground in terms of dependence and self-sufficiency of women and men would seek to put aside family benefits from employment along with spousal deductions in income tax, it would put aside widowhood benefits in pensions when the breadwinner dies, as well as alimony and pension splitting when the breadwinner separates, and it would seek to ensure joint custody of children. All of these things, from family benefits, to taxation, to pension splitting are based on a breadwinner model where one spouse is economically dependent on the other. It is interesting, for instance, that Sweden has never had pension splitting, it has the default condition of joint custody, and it did away with widow's pensions for those who married since 1989. A series of Swedish policies are based on the assumption that adults should be independent rather than dependent.

But even Sweden has not gone far enough in terms of policies that would promote the model of a collaborative family where men and women share both providing and caring responsibilities. In particular, Sweden has strong occupational segregation, and women are much more likely than men to work part-time. There needs to be a better division of leaves and part-time work associated with young children .

In order for the state to absorb more of the costs, might we start our public education system as of age three, joining what has effectively been policy in France for at least twenty years, and following the recommendations of the Ontario Royal Commission on Learning. It is under age three that there is disagreement. Some propose universal child care, and Quebec policy is evolving in this direction. From the National Child Care Survey of 1988 and various other surveys of attitudes regarding care of infants and very young children, there would appear to be considerable interest on the part of parents to absorb the main responsibility through leaves and part-time work (Beaujot, 1997, Ghalam, 1997).

In extending parental leave from 26 weeks to a full year, as of January 2001, did we miss an opportunity to encourage a half year of leave per parent? One could do the same for part-time work. In Sweden, one parent has the right to work part-time, which typically means 30 hours per week instead of the regular 40 hours, until the child is eight years old, and the right to return to full-time work at any point. But Sweden is far from having solved the gender imbalance in work, with women overwhelmingly being the ones working part-time. How about each parent having the right to one year of part-time work, for each child, and the concomitant right to return to full-time work. Of course, part-time work associated with young children would need to come with full social benefits, as it does in Sweden. These are just a few of the relevant considerations. There is 
need for more discussion of provisions that would further modernize the family in the direction of co-providing and co-parenting.

Figure 4

Alternative Models for Family Policy

\begin{tabular}{l|l|l}
\hline & \multicolumn{1}{|c|}{ Complementary Roles } & \multicolumn{1}{|c}{ Equivalent Roles } \\
earning & family wage & two incomes \\
caring & housewife & shared \\
\hline family benefits & yes & no \\
childcare & parental & public or shared \\
leave & extensive & minimal or shared \\
part-time & extensive & minimal or shared \\
security & alimony, pension splitting & economic independence \\
taxation & family level & individual level \\
spousal deduction & yes & no \\
widowhood benefits & yes & no \\
child custody & mother & joint \\
\hline
\end{tabular}


Earning and Caring: Demographic Change and Policy Implications

\section{Acknowledgement:}

Revised version of Distinguished Canadian Demographer Lecture, presented at the University of Alberta, 17 November 2000.

\section{References:}

Balakrishnan, T. R., Evelyne Lapierre-Adamcyk, and Karol J. Krotki. 1993. Family and Childbearing in Canada. Toronto: University of Toronto Press.

Beaujot, Roderic. 1997. "Parental preferences for work and child care," Canadian Public Policy 23(3): 275-88.

Beaujot, Roderic. 2000. Earning and Caring in Canadian Families. Peterborough: Broadview.

Bernier, Christiane, Simon Laflamme, and Run-Min Zhou. 1996. "Le travail domestique: tendances à la désexisation et à la complexification," Canadian Review of Sociology and Anthropology 33(1): 1-21.

Bianchi, Suzanne. 2000. "Maternal employment and time with children: Dramatic change or surprising continuity?" Demography 37(4): 401-414.

Bumpass, Larry L. 1991. "What's Happening to the Family? Interactions between Demographic and Institutional Change." Demography 27: 91327.

Burgess, E.W., H. Locke, and M. Thomas. 1963. The Family: From Institution to Companionship. New York: American.

Church, Elizabeth, 2000. "Women hold just 12\% of power jobs, survey finds," The Globe and Mail 9 February 2000, A1, A9.

Chesnais, Jean-Claude. 1987. "Population trends in the European community 1968-1986," European Journal of Population 3(3-4): 281-96.

Chesnais, Jean-Claude. 1996. "Fertility, family and social policy in contemporary Western Europe," Population and Development Review 22 (4): 729-39.

Coltrane, Scott. 1998. Gender and Families. Thousand Oaks, Cal.: Pine Forge Press. 
Roderic Beaujot

Conway, John F. 1997. The Canadian Family in Crisis. Toronto: James Lorimer.

Côté, James E. and Anton L. Allahar. 1994. Generation on Hold: Coming of Age in the Late Twentieth Century. Toronto: Stoddart.

Davies, Lorraine and Donna D. McAlpine. 1998. "The significance of family, work, and power relations for mothers' mental health," Canadian Journal of Sociology 23(4): 369-87.

Duffy, Ann, Nancy Mandell, and Norene Pupo. 1989. Few Choices: Women, Work and Family. Toronto: Garamond.

Farber, Bernard. 1964. Family Organization and Interaction. San Francisco: Chandler.

Feree, Myra Marx.1991. "Feminism and Family Research," in A. Booth, ed., Contemporary Families. Minneapolis: National Council on Family Relations.

Frederick, Judith. 1995. As Time Goes By. Ottawa: Statistics Canada, cat. no. 89-544.

Gershuny, Jonathan and John Robinson. 1988. "Historical changes in household division of labour," Demography 25(4): 537-52.

Ghalam, Nancy Zukernwick. 1997. "Attitudes toward women, work and family," Canadian Social Trends 46: 13-17.

Giddens, Anthony.1991. Modernity and Self-Identity: Self and Society in the Late Modern Age. Cambridge, United Kingdom: Polity Press.

Goldscheider, Frances and Linda J. Waite. 1991. New Families, No Families? Berkeley: University of California Press.

Hamilton, Roberta. 1978. The Liberation of Women: A Study of Patriarchy and Capitalism. London: Allen and Unwin.

Harris, C.C. 1983. The Family and Industrial Society. London: George Allen and Unwin.

Hochschild, Arlie Russell. 1989. The Second Shift. New York: Viking.

Jones, Charles L., Lorna Marsden, and Lorne Tepperman. 1990. Lives of Their Own: The Individualization of Women's Lives. Toronto: Oxford University Press. 
Earning and Caring: Demographic Change and Policy Implications

Kempeneers, Marianne. 1992. Le Travail au féminin. Montreal: Presses de l'Université de Montréal.

Kluwer, Esther, José Heesink, and Evart Van de Vliert. 1996. "Marital conflict about the division of household labor and paid work," Journal of Marriage and the Family 58(4): 958-69.

Kluwer, Esther, José Heesink, and Evart Van de Vliert. 1997. "The marital dynamics of conflict over the division of labor," Journal of Marriage and the Family 59(3): 635-53.

Lapierre-Adamcyk, Evelyne. 1990. "Faire face au changement démographique: la nécessaire participation des femmes," in R. Beaujot, ed., Faire Face au Changement Démographique. Ottawa: Royal Society of Canada.

Lennon, Mary Clare and Sarah Rosenfield. 1994. "Relative fairness and the division of housework: The importance of options," American Journal of Sociology 100(2): 506-31.

Leridon, Henri and Catherine Velleneuve-Gokalp. 1994. Constances et Inconstances de la Famille. Paris: Presses Universitaires de la France.

Lerner, Gerda. 1986. The Creation of Patriarchy. New York: Oxford.

Livingstone, David and Elizabeth Asner. 1996. "Feet in Both Camps: Household Classes, Divisions of Labour, and Group Consciousness," in D.

Livingstone and J. M Mangan, eds., Recast Dreams: Class and Gender Consciousness in Steeltown. Toronto: Garamond Press.

Lochhead, Clarence. 2000. "The timing of children: Health and social implications of the trend toward delayed first childbirth". Paper presented at Social Cohesion Network Workshop Series, Ottawa, 14 September 2000 .

Luxton, Meg. 1980. More than a Labour of Love. Toronto: Women's Press.

Luxton, Meg. 1990. "Two Hands on the Clock: Changing Patterns in the Gendered Division of Labour in the Home," in M. Luxton, H. Rosenberg and S. Arat Koc, eds., Through the Kitchen Window: The Politics of Home and Family. Toronto: Garamond.

McDonald, Peter. 1997. "Gender Equity, Social Institutions and the Future of Fertility." Australian National University, Working Papers in Demography no. 69. 
Roderic Beaujot

Martin, S.P. 2000. "Diverging fertility among U.S. women who delay childbearing past age 30," Demography 37: 523-33.

Meissner, Martin, Elizabeth Humphreys, Scott Meis, and William Scheu. 1975. "No exit for wives: Sexual division of labour and the cumulation of household demands," Canadian Review of Sociology and Anthropology 12(4): 424-39.

Nevitte, Neil. 1996. The Decline of Deference. Peterborough: Broadview.

Péron, Yves, Hélène Desrosiers, Heather Juby, Evelyne Lapierre-Adamcyk, Céline Le Bourdais, Nicole Marcil-Gratton, and Jael Mongeau. 1999. Canadian Families at the Approach of the Year 2000. Ottawa: Statistics Canada cat. no. 96-321 no.4.

Presser, Harriet B. 1998. "Toward a 24 Hour Economy: The U.S. Experience and Implications for the Family," in D. Vannoy and P.J. Dubeck, eds., Challenges for Work and Family in the Twenty-First Century. New York: Aldine De Gruyter.

Ranson, Gillian. 1998. "Education, work and family decision making: Finding the right time to have a baby," Canadian Review of Sociology and Anthropology 35(4): 517-33.

Ravanera, Zenaida. 1995. "A Portrait of the Family Life of Young Adults," in R. Beaujot, Ellen M. Gee, Fernando Rajulton, and Zenaida R. Ravanera, eds., Family over the Life Course. Ottawa: Statistics Canada, cat. no. 91-543.

Ross, Catherine E., John Mirowsky, and Joan Huber. 1983. "Dividing work, sharing work, and in-between: Marriage patterns and depression," American Sociological Review 48: 809-23.

Roussel, Louis. 1979. "Générations nouvelles et mariage traditionnel," Population 34(1): 141-62.

Scanzoni, Letha and John Scanzoni. 1976. Men Women and Change: A Sociology of Marriage and the Family. New York: McGraw-Hill.

Silver, Cynthia. 2000. "Being there: The time dual-earner couples spend with their children," Canadian Social Trends 57: 26-29.

Spain, Daphne and Suzanne Bianchi. 1996. Balancing Act: Motherhood, Marriage and Employment among American Women. New York: Sage Foundation. 
Earning and Caring: Demographic Change and Policy Implications

Thompson, Linda and Alexis Walker. 1989. "Gender in families: Women and men in marriage, work, and parenthood," Journal of Marriage and the Family 51: 845-71.

Van Leeuwen, Mary Stewart. 1998. "Postmodern Marriage and the Deconstruction of the Culture of Divorce." Presentation, Veritas Conference, University of Western Ontario, London, Ont., 4-5 November 1998.

Yogev, Sara and Jeanne Brett. 1985. "Perceptions of the division of housework and child care and marital satisfaction," Journal of Marriage and the Family 47: 609-18. 
Figure 1. Views of Vancouver men on wives as co-providers, 1971

Ten of the couples in the Meissner et al. (1975) study were interviewed to explore in more depth their feelings and conceptions of the division of paid and domestic work. The selected quotes from five men given below represent the full range of class differences:

A forklift driver in his mid-fifties, whose wife works two days a week as a switchboard operator (three children, aged 13 to 22), had this to say on the conditions of sharing housework: "If a woman has to work, then the husband and wife should share the housework, but if it isn't necessary for her to work then she should consider looking after the house first. It isn't necessary for her to work in the first place. She's doing this for herself and to satisfy herself, where the man has to work to keep the house going."

A skilled repairman in his early forties whose wife had been upgrading her education and is contemplating further training, on the question of his wife taking a job (four children, aged 5 to 16): "I'd want her home when the kids come home from school or at least when I get home from work. I'm sure as hell not cooking my own supper, I didn't get married for that."

A policeman in his early forties whose wife works a few hours a week as a salesperson in a store (two children, aged 9 and 13), on his wife's income: "It doesn't mean anything because it's so little. I told her to put it away into a little account, do whatever you want with it." On reacting to two weeks recently when his wife's job was full time: "To stand back and say there's no way she's going to work steady if this is what it's going to do. It wasn't the money, it was just getting a break from housework to cut the boredom down a little bit and having fun at it and no stress or strain or nothing. Once a job starts to develop the stresses and strains it's not worth it any more. You've lost yours sense of direction."

A manager in his mid-thirties whose wife is a full-time housewife (three children, aged 7 to 14), on the hypothetical question of his wife taking a job: "I wouldn't stand in her way, if that's what she wanted to do, but fortunately for me she doesn't want to do that. My wife's first priority should be the family and the home as long as I am able to provide for the family."

A lawyer in his late forties whose wife has just quit a part-time professional job because the double burden was too much (three children, aged 15 to 19), about the sharing of housework: "If the guy comes home completely beat because he's got a job of much more pressure and his wife has a job because she's bored with the housework, this gives her a lift and she's more up to doing the housework." 


\section{Earning and Caring: Demographic Change and Policy Implications}

Source: Meissner et al., 1975: 438-439. 